\title{
Inculturation and the Guadalupana
}

An estimated 20 million people arrive each year at the Basilica of Our Lady of Guadalupe in Mexico City, making it one of the most visited pilgrimage sites in the world. ${ }^{1}$ The image that resides there, known affectionately as la Guadalupana or la Morenita, has been an object of love and devotion for millions of people over the course of the past half-millenium. But what is it about this symbol that has captured the hearts of so many? In his recent Apostolic Exhortation Evangelii Gaudium, Pope Francis emphasizes "the importance of understanding evangelization as inculturation. Grace supposes culture," he writes, "and God's gift becomes flesh in the culture of those who receive it."2 Expressing themes that have recurred throughout his life and ministry, Francis proceeds to laud the role of popular piety in the life of a people, maintaining that its accessible, incarnate features exemplify the embodiment of faith in culture. Echoing the concluding document of Aparecida, where the Latin American episcopate held its Fifth General Conference in 2007, Francis describes popular piety as a "spirituality incarnated in the culture of the lowly" and "the people's mysticism."3

It would be difficult to find a more significant example of the convergence of these themes of Francis than the celebrated image of Guadalupe, to which the Pope himself will make a pilgrimage in 2016. Using Francis' words in Evangelii Gaudium as a point of departure, this paper presents the Guadalupan image and devotion as a model of inculturation. It focuses upon three key features of the Guadalupana from which can be gleaned broader principles for inculturation in other pastoral contexts, namely: (1) its interlacing of cultural and revelational symbols in such a way that the cultural symbols are affirmed as well as transformed, (2) the use of what Karl Rahner refers to as "primordial" words and symbols that communicate a mysterious "overplus of meaning," illuminating the heart and touching "the core of our being," and (3) finally the use of inculturated symbol to mediate a shared faith that can build dynamic ecclesial community, promote justice in solidarity and engender, to borrow a phrase from Greg Boyle, "exquisite mutuality."4

Nahuatl, the primary indigenous language of Mesoamerica, was recorded using elaborate pictographic codices comprised of images and glyphs..$^{5}$ To the indigenous of Central America, therefore, Guadalupe has long been regarded as more than a mere image; she is, rather, a codex, the symbols of 
which communicate meaning by way of metaphor and consonance. ${ }^{6}$ The imagery of a woman clothed with the sun and the moon under her feet corresponds, of course, with the twelfth chapter of Revelation. But sun and moon, explains Virgil Elizondo, also evoked the divine in Nahuatl, a divinity that reveals itself "between clouds and mists;"7 the woman of the image is surrounded by these ancient cosmic symbols, yet significantly, she stands before and above them, poised to reveal a new message. By the inclination of the woman's head, the praying hands and the fold in her tunic, indicating a slightly lifted knee, the Nahua understood this revelatory woman to be engaged in a solemn and prayerful dance, which was, in Nahuatl culture, the most complete way of reverencing the divine. ${ }^{8}$ The forty-two stars on her mantle depict the pattern of constellations in the Mexican sky at the winter solstice. Above the woman's waist there is a maternity band worn by pregnant indigenous women, and the glyph just below the tassel of the band is a small jasmine flower symbolizing the sun god. ${ }^{9}$ In other words, observe Eduardo Sánchez and José Guerrero, the implication is that the mother of God has come with the dawn of a sacred revelation, amidst the dark depths of winter, bearing within her a divine son who brings light. ${ }^{10}$

In 1531, the year traditionally identified with the Guadalupan event, following ten years of a Spanish conquest in which much of the Aztec-Nahuatl world was destroyed amidst brutal violence and exploitation, there was plenty of darkness in the land. In the traditional cosmology of the Aztecs, a perpetual conflict between sun, moon and stars had put the cosmos itself at constant risk of collapse, and human sacrifices were made to preserve cosmological harmony and prevent such a calamitous occurrence. Against this backdrop, the Guadalupan image conveys cosmic peace and reconciliation; the serene woman bearing new light stands superior to the elements and portends cosmic harmony. ${ }^{11}$ She is also clearly mestiza, blending Spanish and Indian features, and as a mestiza mother bearing new light and new life amidst the prevailing darkness and destruction, an image of ethnic reconciliation and social hope. "Whereas the mestizaje of the conquest was destructive of everyone," reflects Virgil Elizondo, "the mestizaje of Guadalupe is reconstructive of everyone." 12

This becomes especially manifest in the foundational Guadalupan narrative, the Nican Mopohua. ${ }^{13}$ The Nahuatl text is an intercultural narration, explains Richard Nebel, that combines Christian-European with Nahuatl elements in such a way that the indigenous style predominates. ${ }^{14}$ It is replete with Nahuatl literary devices, including "the poetic characterization of person and place," litanies 
of parallel expressions, couplets that issue metaphorically in a third concept, and diminutive forms of address. ${ }^{15}$ Once again, central elements of the Gospel are translated into a diverse lexical and semantic system expressed in metaphors and symbols. ${ }^{16}$ Birdsong and flowers signify, for the Nahuas, "the aesthetics of sacred space," "the language of encounter with the divine." ${ }^{\prime 17}$ Amidst flower and song, flor $y$ canto, Juan Diego encounters Mary at a mount, the classic Nahua and biblical place of theophany. The particular mount in the narrative, Tepeyac, was the site of a pre-existing cult to the Aztec goddess Tonantzin, meaning "our venerated mother."18 Franciscan missionaries would long discourage the Guadalupan devotion on account of its association with Tonantzin, and its perseverance is an indication of what encounters between Greco-Roman civilization and Christianity in antiquity already showed: grace supposes culture and builds upon it. Here the pre-existing culture is at once affirmed as well as healed, dignified as well as transformed. Whereas Franciscan missionaries dismissed the Aztec wise men who argued that the supreme principle, Téotl, which they had worshipped, was the same God as the Spanish Dios, in the Nican Mopohua Our Lady of Guadalupe refers to herself as the mother of God using a litany of Nahuatl expressions for the divine, and the first notably combines Nahuatl with Spanish: she is the mother of "Téotl Dios." Using a classic litany of parallel Nahuatl expressions that also bear biblical resonance, the mother of God refers to herself in the narrative as "holy Mary, mother of the true Téotl Dios, Ipalnemohuani, the giver of life; Teyocoyani, the Creator of people; Tloque Nahuaque, the Owner of what is near and together; Ilhuicahua, the owner of the heavens; Tlaticpaque, the owner of the face of the earth." 19 This is, Richard Nebel observes, "evangelization as dialogue, not evangelization as spiritual conquest." 20

In a context in which the native peoples had been excluded from the clergy and their capacity for the sacraments had even been questioned, it also highly significant that Mary chooses Juan Diego, who describes himself in the narrative using another litany of heartbreakingly deprecatory terms. He is not only identified as a macehual, or poor commoner, but he describes himself as "a piece of rope," a "ladder" to be stepped on, "the excrement of people." 21 His self-description stands in strong contrast, however, to the dignified titles of affection by which Mary calls him, using Nahuatl diminuitive forms of address that express intimacy, affection and respect: "Juantzin, Juan Diegotzin," she calls him. ${ }^{22}$ She will have none of his protests of unworthiness: he is the one who will bear the message to the bishop, and in a 
twist of exquisite mutuality, it is the bishop who is ultimately brought to new belief by the apostolic macehual Juan Diego. Undoubtedly, writes Nebel, "liberation from marginalization for the indigenous peoples is a basic demand of the Nican Mopohua," 23 a marginalization that is replaced, to the use the apt phrase of Virgil Elizondo, by a new "spiritual mestizaje," ${ }^{24}$ characterized instead by mutuality and reconciliation. This dynamic is initiated and led by the mestiza Virgen, who describes herself in the Nican Mopohua, as the "compassionate mother" of "all those who live together in this land and also of all other nations," who has come to give "[her] love, [her] compassionate gaze, [her] help, [and her] protection," to hear at Tepeyac the "weeping and lament" of the people and remedy "their miseries and sorrows." 25 As a representation of the most essential features of the Gospel, it is no surprise that the Guadalupan sermons of the seventeenth and eighteenth centuries would refer to our Lady of Guadalupe as the "apostle of the Americas." ${ }^{26}$ She remains such an apostle for millions today, an apostle who embodies unconditional mercy and compassion for all while also serving as an advocate on behalf of the marginalized and downtrodden, those regarded by an indifferent society as "ladders to be stepped on."

If, however, our Lady of Guadalupe is to be a patroness of all the Americas, as John Paul II named her, it is also important to highlight the ways in which this image and narrative bears transcendental elements that can be shared cross-culturally. Indeed, Rahner's theory of the urwort and ursymbol would indicate that another reason this image and narrative have proven so compelling is because of these more transcendental elements. In the third volume of Theological Investigations, Rahner introduces the notion of the primordial word. Even as, he explains, thought becomes incarnate in language in ways that cannot be translated, for "the noche of a John of the Cross and the Nacht of a Novalis or a Nietzsche are not the same," there are certain fundamental words that are not so "arbitrarily determined" and that therefore have unique cross-cultural power to "harmonize in unity." These are words that "bring light to us, not we to them," that convey an "overplus of meaning" and render things "translucent" to the infinite mystery. Unlike "fabricated, technical, utility words," primordial words touch the heart, the core of our being, and "form the basis of man's spiritual existence." 27 When spoken, they bear within them an efficacious capacity to deliver a kerygma, to communicate love, to mediate grace. They are words that can be described just as Juan Diego describes the words of Mary in the Nican Mopohua: "exceedingly re-creative, very ennobling, alluring, producing love." ${ }^{28}$ Remarkably, many of 
the same words that Rahner uses as examples of urworte also appear in the Nahua text: "blossom," "night," "star," "rose," "heart." 29 Could we not also include many other key words from the Nican Mopohua such as, "mother," "song," "dream," "dawn," "sun," "flower," "hillside," "face," "heaven and earth?" While the constraints of space do not permit us to fully situate the meaning of these deep words within the text, the basic implication remains: do they not represent a universally appealing aesthetic, a poetic and spiritual theology ideally suited to facilitate an experience of the divine?

But of course, the primary object of Guadalupan devotion is not a text, but an image. Here Rahner's theory of the ursymbol, which he developed to explicate the Sacred Heart, can also be effectively employed. Unlike representations that signify by convention, there are certain original, archetypal, "primordial symbols," according to Rahner, that prove "irreplaceable" and that cannot be reduced to a more abstract, conceptual analysis. This is because their meanings correspond with certain basic human spiritual-corporeal experiences, generating a primordial correspondence between symbol and reality, such as with love and the heart, Rahner argues, or in our own case, the correspondence between compassion and a mother's abiding presence and love. ${ }^{30}$ Can we not all relate to the mystery of maternal compassion conveyed by this image, just as we can all relate to the poetic and revelatory features of blossoms, song, sun and hillside? In other words, is this not an image and a story that can affect us all? Though the meaning of both narrative and image are clearly maximized when understood in an inculturated sense, are there not also transcendental aspects of their message that can speak simply on the basis of shared human experience? Finally, are not the most effective forms of evangelization always inculturations that maximize the use of urworte and ursymbol so as to effect a reception of the Gospel that resounds in the depths of the heart?

In light of all that has been said, it is not hard to understand why the Guadalupana became for seventeenth-century Mexico a "master symbol around which all the great hopes and desires of a society and nation coalesced." 31 All were hijos de Guadalupe, recipients of her universal love and followers of the light she bore within. She inspired faith in such a way that diverse cultures, ethnicities and classes could unite around a common symbol, to the point at which it became perhaps the principal symbol of a nation's identity. After her visitation, runs the popular song entitled la Guadalupana, "desde entonces para el mexicano / ser Guadalupano es algo esencial' [from then on, for every Mexican, / being 
Guadalupan is something essential]." But the image of Guadalupe has not only been an image that unites communities in faith; it has also proven a dynamic symbol through which they can pursue social transformation. In 1810 Miguel Hidalgo famously made Guadalupe the rallying symbol of liberation in the Mexican War of Independence; Viva Cristo Rey y la Virgen de Guadalupe was the essential rallying cry of the Cristeros of the late 1920s; Cesar Chavez placed her banner at the head of his famous march of the National Farm Workers Association from Delano to Sacramento in 1966; and more recently, of course, she has served as a vital instrument of consolation for millions of migrants who make the arduous, often life-threatening journey north, often traveling with her image emblazoned upon the little they possess. In other words, Guadalupe embodies a popular piety that has served not only to build up ecclesial community in shared faith, but amidst marginality and oppression, has proven an effective symbol of liberation, a sure means of promoting justice in solidarity.

She remains, in the words of Mexican Nobel laureate Octavio Paz, "impressed on the heart of Mexico... [as] the solace of the poor, the shield of the weak and oppressed." 32 In a social scientific study of the impact of the symbol of Guadalupe upon the "faith life of Mexican-American women," Jeanette Rodriguez provides abundant first-hand data about how Guadalupe has served for them as a "role model of strength, enduring presence, and new possibilities" as well as a cause of “joy, identification, peace, comfort and understanding." 33 Colleen Cross observes that in the Nican Mopohua it is our Lady of Guadalupe that leads both Juan Diego and the bishop — in spite of the social disparity between them-into a shared "mystical encounter," an encounter in which, ultimately, each is reconciled and "transformed through her love to a place" of mutuality and communion. ${ }^{34}$ Amidst the many manifestations of injustice, brokenness and marginalization in our Americas today, the symbol of Guadalupe remains a source of hope, a hope that shared faith, mediated through incarnate, accessible symbols that Pope Francis calls the “people's mysticism," can yet again engender for us all profound reconciliation and transformation, converting the mighty from their thrones and lifting up the lowly so as to effect a new communion, an "exquisite mutuality." 
${ }^{1}$ Fred de Sam Lazaro, “Our Lady of Guadalupe Basilica," PBS Religion \& Ethics Newsweekly, November 21, 2014, http://www.pbs.org/wnet/religionandethics/2015/08/07/november-21-2014-lady-guadalupe-basilica/24655/.

${ }^{2}$ Pope Francis, Evangelii Gaudium, (Washington, DC: United States Conference of Catholic Bishops, 2013), 115.

${ }^{3}$ Ibid., 124.

${ }^{4}$ Greg Boyle, "Q\&A With Greg Boyle,” in Tattoos on the Heart (New York: Free Press, 2010).

${ }^{5}$ Images and painting were so central to Nahua culture that its creation myth portrayed God "painting everything through flowers / through song, dispensing colors to each living thing here on the earth," in Fidel González Fernández, Eduardo Chávez Sánchez, and José Luis Guerrero Rosado, El Encuentro de la Virgen de Guadalupe y Juan Diego (Mexico: Editorial Porrúa, 2000), p. 208.

${ }^{6}$ The Guadalupan sermons of the $17^{\text {th }}$ - and $18^{\text {th }}$-centuries demonstrate a striking and prescient appreciation for the inculturated nature of the image: in 1660, Joseph Vidal de Figueroa noted how God's grace is "always conforming itself to the nature in 1747, Antonio de Paredes lauded how Mary "accommodated herself to the usage of the indigenous peoples," thereby saying more than the Scriptures could express;" in 1757 Juan Joseph de Eguiara y Eguren explained that the "whole Guadalupan Image is a Book," all cited in Francisco Raymond Schulte, OSB, Mexican Spirituality: Its Sources and Mission in the Earliest Guadalupan Sermons (New York: Rowman \& Littlefield, 2002).

${ }^{7}$ Ibid., p. 204; Virgil Elizondo, Guadalupe: Mother of the New Creation (Maryknoll, NY: Orbis, 1997).

${ }^{8}$ Fidel González Fernández, Eduardo Chávez Sánchez, and José Luis Guerrero Rosado, El Encuentro de la Virgen de Guadalupe y Juan Diego (México: Editorial Porrúa, 2000), p. 203. Cf. Carl Anderson and Eduardo Chávez, Our Lady of Guadalupe: Mother of the Civilization of Love (New York: Doubleday, 2009), 38.

9 Jeanette Rodriguez, Our Lady of Guadalupe: Faith and Empowerment among Mexican-American Women (Austin: University of Texas Press, 1994), 29.

${ }^{10}$ Fidel González Fernández, Eduardo Chávez Sánchez, and José Luis Guerrero Rosado, El Encuentro de la Virgen de Guadalupe y Juan Diego (México: Editorial Porrúa, 2000), p. 197, 212-213. On the unique significance of the dawn as a symbol of apocalyptic re-creation, cf. Michael Anthony Abril, "Apocalypse at Tepeyac," in New Frontiers in Guadalupan Studies, ed. Virgil Elizondo and Timothy Matovina (Eugene, OR: Pickwick, 2014), 130-132.

${ }^{11}$ Ibid., 213-214. "In a 1995 interview, the Indians of Zozocolco, Veracruz, while preparing to celebrate the feast of Our Lady of Guadalupe, explained: "With the harmony of the angel, who holds up the Heavens and the Earth, a new life will come forth. This is what we received from our elders, our grandparents, that our lives do not end, but rather that they have a meaning... This is what we celebrate today.. the arrival of this sign of unity, of harmony, of new life," ctd. in Carl Anderson and Eduardo Chávez, Our Lady of Guadalupe: Mother of the Civilization of Love (New York: Doubleday, 2009), 36.

${ }^{12}$ Virgil Elizondo, Guadalupe: Mother of the New Creation (Maryknoll, NY: Orbis, 1997), 112.

${ }^{13}$ Due to the immense and labyrinthine nature of the historiographical debate regarding the provenance of the Nican Мороһиа, this brief article must prescind from making any comment in this regard. Nonetheless, reference should be made to the evidence presented by esteemed Nahuatl scholar Miguel León-Portilla in his erudite study, Tonantzin Guadalupe, in which he limns a highly compelling case for why the original Nican Mopohua has rightly been ascribed to Antonio Valeriano and dated to the mid-sixteenth century. Cf. Miguel León-Portilla, Tonantzin Guadalupe (México: El Colegio Nacional and Fondo de Cultura Económica: 2000).

${ }^{14}$ Richard Nebel, Santa María Tonantzin Virgen de Guadalupe: Continuidad y transformación religiosa en México trans. Carlos Warnholtz Bustillos (México: Fondo de Cultura Económica, 1995), 218-219.

${ }^{15}$ D.A. Brading, Mexican Phoenix: Our Lady of Guadalupe: Image and Tradition Across Five Centuries (Cambridge: Cambridge University Press, 2001), 83; Miguel León-Portilla, Tonantzin Guadalupe (México: El Colegio Nacional and Fondo de Cultura Económica: 2000), 22. León-Portilla observes: "Hay en este texto una exposición de ideas clave en el pensamiento Cristiano, arropadas en el lenguaje y forma de concebir el mundo de los pueblos nahuas" (68). 
${ }^{16}$ Richard Nebel, Santa Maria Tonantzin Virgen de Guadalupe: Continuidad y transformación religiosa en México trans. Carlos Warnholtz Bustillos (México: Fondo de Cultura Económica, 1995), 219. Nebel furthers: "La forma y el contenido se compenetran entre sí: lo cristiano se hace 'mexicano,' lo mexicano se vuelve 'cristiano."'

${ }^{17}$ Michael Anthony Abril, "Apocalypse at Tepeyac," in New Frontiers in Guadalupan Studies, ed. Virgil Elizondo and Timothy Matovina (Eugene, OR: Pickwick, 2014), 128. For an in-depth survey of the origins of these words and symbols in ancient Nahuatl poetry and codices, see Miguel León-Portilla, Tonantzin Guadalupe (México: El Colegio Nacional and Fondo de Cultura Económica: 2000), 51-60.

${ }^{18}$ Richard Nebel, Santa María Tonantzin Virgen de Guadalupe: Continuidad y transformación religiosa en México trans. Carlos Warnholtz Bustillos (México: Fondo de Cultura Económica, 1995), 90.

${ }^{19}$ This translation was made by the author from the Spanish version of the Nican Mopohua of Miguel Léon-Portilla while preserving the Léon-Portilla's juxtaposition of the original Nahuatl words beside the vernacular translation: Miguel León-Portilla, Tonantzin Guadalupe (México: El Colegio Nacional and Fondo de Cultura Económica: 2000), 100-103.

${ }^{20}$ Ibid., 250; cf. Colleen Cross, “The Guadalupan Covenant,” New Frontiers in Guadalupan Studies, ed. Virgil Elizondo and Timothy Matovina (Eugene, OR: Pickwick, 2014), 118.

${ }^{21}$ Virgil Elizondo, Guadalupe: Mother of the New Creation (Maryknoll, NY: Orbis, 1997), 10.

${ }^{22}$ Cf. Rosa María Icaza, C.C.V.I., "Who Can Help Us Better to Prepare for Christmas?," The Treasure of Guadalupe, ed. Virgil Elizondo, Allan Figueroa Deck, and Timothy Matovina; Carl Anderson and Eduardo Chávez, Our Lady of Guadalupe: Mother of the Civilization of Love (New York: Doubleday, 2009), 119.

${ }^{23}$ Richard Nebel, Santa María Tonantzin Virgen de Guadalupe: Continuidad y transformación religiosa en México trans. Carlos Warnholtz Bustillos (México: Fondo de Cultura Económica, 1995), 261.

${ }^{24}$ Virgil Elizondo, Guadalupe: Mother of the New Creation (Maryknoll, NY: Orbis, 1997), 110.

${ }^{25}$ Miguel León-Portilla, Tonantzin Guadalupe (México: El Colegio Nacional and Fondo de Cultura Económica: 2000), 102-103.

${ }^{26}$ This can be observed, for instance, in the sermon of Joseph Camancho y Palma preached in 1758 in which he refers to Mary as "the Apostle of this new Orb," or that of Francisco Xavier Lascano in the same year, who claimed that the apostolate of the Americas "was reserved for Mary," as cited in Francisco Raymond Schulte, OSB, Mexican Spirituality: Its Sources and Mission in the Earliest Guadalupan Sermons (New York: Rowman \& Littlefield, 2002), 85-96. Schulte documents how further sermons clearly follow in the same tradition and expand upon it, but all share in attributing the principal role in the evangelization of America to a Guadalupan Mary.

${ }^{27}$ Karl Rahner, Theological Investigations: Volume III, trans. Karl-H. and Boniface Kruger (Baltimore: Helicon Press, 1967), 295-297.

${ }^{28}$ Virgil Elizondo, Guadalupe: Mother of the New Creation (Maryknoll, NY: Orbis, 1997), 7.

${ }^{29}$ Karl Rahner, Theological Investigations: Volume III, trans. Karl-H. and Boniface Kruger (Baltimore: Helicon Press, 1967), 298.

${ }^{30}$ Ibid., 327-330.

${ }^{31}$ Richard Nebel, Santa María Tonantzin Virgen de Guadalupe: Continuidad y transformación religiosa en México trans. Carlos Warnholtz Bustillos (México: Fondo de Cultura Económica, 1995), 146.

${ }^{32}$ Quoted in Paul Badde, Maria of Guadalupe, trans. Carol Cowgill (San Francisco: Ignatius Press, 2008), 71.

33 Jeanette Rodriguez, Our Lady of Guadalupe: Faith and Empowerment among Mexican-American Women (Austin: University of Texas Press, 1994), 160-162.

${ }^{34}$ Colleen Cross, "The Guadalupan Covenant," New Frontiers in Guadalupan Studies, ed. Virgil Elizondo and Timothy Matovina (Eugene, OR: Pickwick, 2014), 121. 